IIUC STUDIES

ISSN 1813-7733

Vol.- 7, December 2010

(Published in December 2011) (p 221-240)

\title{
The Tendency of Breaking Arranged Marriages in Indian Subcontinent and Ways of Peaceful Co-Existence in the light of Islam
}

\author{
Md. Masudur Rahman*
}

\begin{abstract}
Breaking arranged marriage has become of late a common phenomenon in the Muslim society of the Indian sub continent. For this, misunderstanding, clash and quarrels break out inside the family and society. Family loses money, peace and tranquility. This is disgusting burden for the society and obstacles to development also. This article discusses the reasons of breaking arranged marriages and has given a suggestion to reduce the tendency of misunderstanding of the conjugal life in the light of the religion of Islam.
\end{abstract}

\section{Introduction}

The ratio of breaking arranged marriage in Indian subcontinent increases day by day. There are many reasons behind these unexpected behaviors which may be overcome by Islamic ideals and teachings. Many Islamic thinkers suggested enough positive opinions to create peace and tranquility in the family life. But unfortunately, no Muslim heeds to any kind of these ideals or examples and suggestions or request made by the Muslim scholars. Falling in love is not a precondition for marriage in Islam. However, for the purpose of selecting an appropriate mate or partner, the would-be-spouses are allowed to meet or to talk to each other. Marriage and the family are central in the Islamic system. There are many passages in the Qura' $n$ and statements by the Prophet (sm) which go as far as to say that when a Muslim marries, he has thereby perfected half his religion; so let him be Allah fearing and careful with the other half. To be a good wife is so

* Lecturer in Islamic Studies, Center for University Requirement Courses (CENURC), IIUC. 
important from the view point of Islam that a good wife is considered to be the best possession in the world. On the other hand, the best man is considered to be one who is the best and kindest to his wife. Acting kindly towards one's wife is an Islamic conduct. In this paper my attempt is to focus on the reasons or tendency for breaking arranged marriage and how to reduce or calm down this growing custom in our practical life, in Indian subcontinent.

\section{The tendency of breaking arranged marriages:}

\section{(1)}

For the differences of culture and civilization misunderstanding can arise in newly conjugal life after getting married. The attraction of men to the beautiful body of women and the attraction of women to the handsome body of men decrease gradually. For this reason a girl from a rich family should not get engaged in marital bond with a miserly person. Danger of future does not end only by forcing a man or woman to get engaged with a spouse anyhow. Maladjusted bond does not last long. It is better, if marriage or relationship occurs within a family having same mentality of culture. But in modern age, guardians and society do not care about these matters while contracting marriage. For this reason the cases of dissolution and divorce is increasing day by day in our society.

Marriage in Islam in contractual where both husband and wife are bound by certain regulations and obligation. Islam preaches that Muslim woman cannot be legally forced into marriage without her consent. In the Human Rights Convention importance has been laid on consent of man and woman for marriage. CEDAW (Convention on Elimination of all forms of Discrimination Against Women) also demands for the consent of man and woman for marriage. (Khanum,Vol.15, p.71).

لا تنكح الايم حتى تستتأمرولا تنكح البكرحتى تستأذن. The Prophet (sm) says,

"A matron should not be given in marriage except after consulting her; and a virgin should not be given in marriage except after her permission." (Muslim, Hadith No.1419, p.1036). 
(2)

Till now, guardians choose bride and groom in many local and urban areas of Bangladesh, Pakistan and India following the ancient tradition. Most of the people do not like to expose prospective bride to prospective groom for selection. They think that it is insulting for them. Society does not want to understand what consequence will ensue if marriage is held contrary to the likeness of the bride and groom. "It is necessary for a man to see the woman he intends to marry, and for a woman to see the man she intends to marry." (AlKaysi, p.118). In some cases, girls are being forced to tell or recognize (Kobool). "If the woman refuses, the authority of the guardian cannot be exercised against her will." (Khanum, Vol.15, p.119). Regarding these facts Allah advised us:

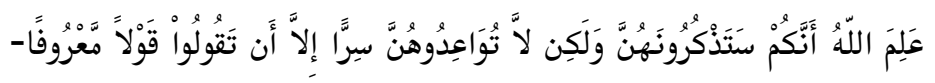

"Allah knows that you will remember them, but do not make a promise of contract with them in secret except that you speak an honorable saying according to the Islamic law." (Al-Qur'an:2:235)

The society of Indian subcontinent moves in its own course. It does not care for any counsel. By the pressure of society, life styles of many people are being broken. It is a matter of regret that the people of the society are not taking lessons from the aforementioned incidents even after observing them directly. "The woman's guardian has no right at all to make the marriage decision. The only one who has the full right to accept marriage is the woman herself, free from any kind of pressure." (Khanum, Vol.15, p.119). Regarding such attitude the Islamic view is:

"The Qura'n (4:21) refers to marriage as a mithaq, i. e. a solemn covenant or agreement between husband and wife, and enjoins that it be put down in writing. Since no agreement can be reached between the parties unless they give their consent to it, marriage can be contracted only with the free consent of the two parties. The Prophet (sm) said, "The widow and the divorced woman shall not be married until their order is obtained and the virgin shall not be married until her consent is obtained." (Al-Bukhari) The Prophet (sm.) further opines: "When a man gives his daughter 
in marriage and dislikes it, the marriage shall be annulled." "Once a virgin girl came to the Prophet and said that her father had married her to a man against her wishes. The Prophet gave her the right to repudiate the marriage. (Abu Dawud)" (Noordeen, p.35).

\section{(3)}

In a conjugal life every one of the spouse wants to enjoy each other. Every husband and wife is enjoyable to each other. So, they should maintain the sweetest relationship with each other. One should follow the other's appetite and pleasure. Otherwise, love and affection is not possible. Possibly a religious man who would not like a highly ambitious wife. Because, a highly ambitious wife desires an impious man as her husband. The rule and discipline of conjugal life should be followed by the spouses. Otherwise, misunderstanding and quarrel would occur among them. If a wife of any young man dedicates her whole attention to religious action only, she would actually do injustice to her husband. Society and guardians cannot comprehend it. The mind of human being also wants foods like the body of human beings. The foods of heart are joy, pleasure, love, affection, assistance, and friendly talking. It can happen that a person may get likeminded person who may suit to be his or her life partner; but their guardians and parents do not accept it. They even do not hesitate to oppose and torture him or her and force him or her to get married elsewhere. As a result, newly getting married persons do not see peace and tranquility in their conjugal life. Famous Islamic thinker Hamudah Abdalati opines that

The idea that love is blind and is the decisive factor in mate selection is not the universal norm of any society, notwithstanding some popular misconceptions". The belief that "love and marriage go together like a horse and carriage" has been drummed into the heads of western young people so insistently that they consider it entirely natural, indeed, necessary. The idea is quite without historical support. Love and marriage are two modes of experience that are by no means identified with each other or with normality. Mate selection has been governed by rules and considerations that may or may not include the priority of love. (Abd al-ati, 1977, pp.84-85). 


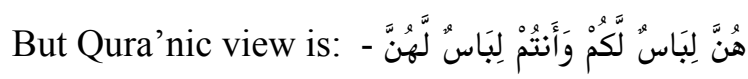

"They are your garments and you are their garments" (AlQur'an:2:187)

(4)

After getting married, if the daughter (wife) criticizes or ignores the husband, her parents think that the daughter is in favor of them. If she shows or exposes more and more love and affection to her husband, they think that the daughter is over devoted to the husband. Similarly, if the husband wants to love his wife; parents, and sister-in-laws all of them believe that their son has got detached from them. They do believe to term the wife as a danger coming from somewhere to take away their son or brother. Some one feels jealous and talks with the new bride pinching her at any chance. If the son (husband) hates, insults his wife in front of his relatives, every one of his relatives praises him. "To dwell on and count a wife's mistakes, to disapprove of her deeds, and to blame her frequently will endanger a marriage. Husbands are advised to ignore their wife's mistakes in any cases." (Al-Kaysi, p.93). It is also true that "For a husband to blame his wife or disapprove of her acts in the presence of others, such as their children, relatives etc., is a rude conduct." (Al-Kaysi, p.93).

(5)

Mother-in-law and daughter-in-law quarrel with each other in the village area even urban area of Indian subcontinent in many cases of family life. Mother-in-law wants to be a teacher of her new daughterin-law. She shows malice, envy to her daughter-in-law. If the house of father-in-law becomes the house of a learning centre like a school or a jail, it is very pathetic.

It is also seen that some of the mother-in-laws (of the ladies) are very mischievous in nature. They create trouble for the sons and daughters-in-law out of their ignorance of the Divine Laws, or lack of common sense, though sometimes inadvertently, and in good faith. They poison their son's ears against the daughters-in-law and cause disputes between them. Perhaps these happenings occur in every house irrespective of its financial status. This is somewhat impertinent on the part of the relatives whether they 
are mothers-in-law or sister-in-law. They must think that the new girl has also every right of participating in family matters after her marriage. The mother-inlaw forgets that once she too was somebody's daughter-in-law. Such mother-in-law shall be put to task in the court of Allah on the day of resurrection, where nobody will avail of anybody else. (Sabiruddin, pp.55-56).

Before getting married, women should be taught family conducts and manners in addition to their academic education. Otherwise the life of women can be sorrowful. Parents, relatives and society should examine the prospective bride whether she is eligible or not to maintain husband's family.

The daughters-in-law should not forget that they too have children, and shall be in the same predicament one day. They are also future mothers-in-laws. If they do not like to deviate from their way which is based on prejudices, false pride, hatred and disrespect for the elders, they should also be prepared to be paid back in the same coin." (Sabiruddin, pp.59-60). "Taking care of the house and running the household are the wife's responsibility. Therefore, she should carry out duties in keeping the house, furniture etc., and be frugal. (Sabiruddin, p.96).

Remember that husband-wife both are complimentary to each other. If it is overlooked, conjugal life is not possible by them. The Prophet (sm) described the features of couple:

$$
\text { التى تسره إذا نظر، وتعيطه إذا أمر، ولا تخالفه في نفسه وماله. }
$$

"She who pleases one when he looks at her, obeys him if he orders, does not disobey him in respect of his person and property". (AlNasa'i, Hadith No.3231, p.68).

"In the family, the man is charged with duty of being leader of the family and the woman is assigned the duty of looking after the household. Even if the man has more responsibility than the women and thereby has a degree over her, it does not make husband 
inherently better than his wife. The Qura'n contains a verse which says:

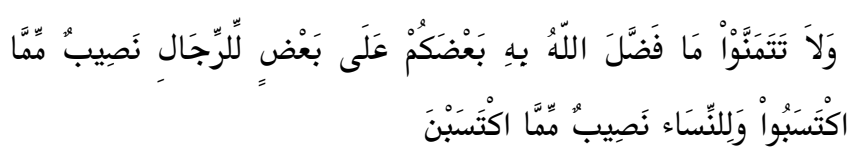

'And in no wise covet those things in which Allah has bestowed His gifts more freely on some of you than others: to men is allotted what they earn and to women what they earn...(4:32)' "(Noordeen, p.11).

Husband should be careful to the essential and due right of his wife.

What is true of lodging is also true of clothing, food, and general care. The wife has the right to be clothed, fed and cared for by the husband, in accordance with his means and her style of life. The right is to be exercised without extravagance or miserliness. For instance, if the wife has been used to having a maid or if she is unable to attend to her domestic affairs, it is the husband's duty to provide her with at least one maid if he can afford it. This is derived from the statements of the Qura'n and the Sunnah. (Abd al-ati, 1977, p.150)

A good relationship with the wife is the foundation of peace and tranquility in social, economical and political life.

Moreover, the Prophet is reported to have declared that the best Muslim is one who is the best husband. On various occasions he called upon his followers to take good care of, and show kindness toward their wives. He warned that the man who remains in the state of anger with his wife is a man whose prayers will not be answered and whose good works will not be accepted. (Abd al-ati, 1977, p.150)

The Prophet (sm) also clearly said: خيركم خيركم لأهله ، وانا خير لأهلي.

"The best of you is one who is best to his family and I am the best to my family". (Al-Tirmidhi, Hadith No.3895, p.709) 
(6)

Most of the families in our society feel jealous when they find a new bride happy, joyous and comfortable in her family life. Everyone in a family gives priority to his or her own interest. In such family, divorce or dissolution happens usually. If everyone tries to find fault, criticizes, blames, a newly married woman who has come to a new environment as a bride leaving behind all her relatives, parents, brothers, sisters etc.; she becomes completely puzzled and loses whatever intelligence she possesses. In some families, there are people who do not hesitate to abuse, poke, criticize even beat the newly married bride even at the smallest fault from her. If she makes any mistake, everybody rushes to her furiously. For this reason, misunderstanding is increasing day by day.

(7)

The prospective bride and groom should feel and understand each other well, so that misunderstanding does not rise among them after marital contract. One will have to choose a spouse according to one's attitude and taste. There should have attraction between prospective bride and groom. Lack of eagerness and affection, all kinds of qualities a person might have, may look blurred. On the other hand, if there is love and affection, an ugly or wicked woman may seem attractive and inviting to a man. In the social system of Bangladesh, some gentle men think that exposing daughter to the prospective groom before marriage is one kind of insulting matter. But after marital contract, if conflict arises between husband and wife then parents can do nothing. The daughter has to be oppressed and tortured in future. Such heart breaking examples are available in thousands of houses in Bangladesh and her neighboring countries. After marital contract, many husbands leave their wives. They go to prostitutes. They do not look at the face of their beautiful wives. Rather, they get attracted to wicked and nasty women. The consequence of such conduct is very dangerous. Cruel or non-flexible parents do such work to their own son and daughters. If they get a chance to see, talk and love each other before marital contract, why it would be insulting for them. But society does not support it. From the survey and analysis of polygamy among men and women, it has been found that one of its causes is the lack of mutual understanding, love and attraction; the minds of husband and wife, specially the minds of husband are always dissatisfied to each other. As a result, male marries more than one woman and thinks that it will bring satisfaction. But lack of love and attraction, if one get married to thousands of women, he will never get satisfaction. Rather the flame of dissatisfaction increases day by day. The mind of wife who has no love 
and attraction to her husband always remains dissatisfied. She always groans and remains upset for not getting expected person. Lack of eagerness and attraction before marital contract, they misbehave with each other after marriage. One can neither tolerate the other nor break their bondage. So, the greatest elements of conjugal life are love, devotion and passion.

When a marriage is contracted, there must be a direct, unequivocal proposal followed by a corresponding acceptance thereof. Both proposal and acceptance must be explicit and oral if the contracting parties are present in person. Otherwise a written form may be substituted for the oral. That is not the same as having the contract registered after its conclusion, a procedure which seems to have been introduced in later periods for administrative purposes. (Abd al-ati, 1977, p.60)

The name of the conjugal life is the life of sacrifice. So, more sacrifice brings more benefit.

The family in Islam is a unit in which a man and woman unite to share life together according to the rules and regulations laid down by the Sharia. They become as close to each other as a garment is to the body. The husband's honor becomes as an integral part of wife's honor, and vice versa. They share each other's prosperity and adversity. Thus in Islam the bridal couples are united as husband and wife in the presence of witnesses seeking Allah's blessings to increase in mutual love and compassion and agreeing to care for each other in sickness and adversity. (Noordeen, p.11).

Any kind of extra marital affairs would not be tolerated in the conjugal life. It can influence badly on the new born child of the couple.

No women would like her husband to have sex with anybody except with her. The extra marital pursuits damage the marital relationships. Heart breaks in the broken relationship are at times very painful. They regret such accidental lapses and painfully watch the after-effects on the children. (Shamsul Alam, p.138). 
(8)

It is not a right way to live anywhere lonely, after getting married leaving behind the wife. The newly couple whether may be poor or rich, if both share difficulties and problems of family life together, every problem of family life would be easy and light to them. Recently, it is observed that many young persons leave the house after getting married for searching job abroad. For long time they do not maintain communication with their wives. In consequence, internal conflict rises among them. As the organs of the body like hands and legs are not burdens for a man, wife is also not a burden for a husband. A wife completes the life of a husband as physical limbs complete the structure of a human body wherever one should live whether it would be in the field or under the tree or in the bush or in a slum; one will have to stay, live with one's wife. Some wives do not trust their husbands. They think that their parents and brothers or sisters as their only well wishers. Such kind of thinking is a heinous offence for a wife. "A good wife is one who is true to her husband's word if he adores her to do something." (Al-Kaysi, p.95).

(9)

It is better for a person to select bride or bridegroom from familiar persons. It is better also to choose any girl from the neighbors, close relatives and well known family. Without knowing, without understanding, it is too tough task to marry an unknown girl suddenly. It is a kind of cheating to the mind. Our hearts do not get any satisfaction. After this kind of contract, spouses do not want to accept one another in any case. Sexual demand gets fulfilled surely but the demand of mind still remains in dream. But our social system and custom do not want to bring about a change of such fractions. In some cases, the guardians of both parties conceal their real intention behind their effort to establish a relationship and thus they destroy the lives of bride and groom. In the minds and conscience of guardians, these facts and life destroying initiatives may seem a very simple matter. For such destructive decision of society, lifelong sufferings turn the conjugal life of a couple topsy-turvy. As a result this conjugal life suffers until death like fire of husks. No one's marriage can be blocked in this world. It will occur any time. Any man or woman will look handsome or beautiful to him or her would be spouse. If one's beauty does not attract one's eye or fails to satisfy one's mind, there is no value for this beauty. Would not the society and relatives understand it? 
(10)

Watching dish, cinema and blue film; young generation hankers after towards imagined girls, dreams of heavenly night and day and honey moon with an unseen girl. After marital contract they want that imagined girl in their practical life. They do not know whether it would be possible or not to convert the imaginary thinking into a real life. Many educated young men blame their wives, express dissatisfaction for not getting that fancied charms in their wives according to their dream and imagination. It is not possible to get dream and imagination materialized in this earthly life. Someone repents immediately after getting married with a woman. If any mistake occurs, this mistake can be rectified in any way. Divorcing or leaving the wife is very shameful and disgraceful.

\section{(11)}

There are many husbands and wives who are unable to meet with each other at the day and night on account of their business. Everyone is busy in their own profession. The time of sweet talking and telling story is unavailable to them. Such life is detrimental to the conjugal life. Detachment between husband and wife because of too much engagement make conjugal life tasteless and sorrowful. Only sexual intercourse is not enough in the life of human being. The soul of human being demands something more. In this sorrowful and intolerable human life, service and work is not enough; life should be made joyful and juicy. A wife does not usually go to the house of a husband just for working there in the manner one serves at an office under a supervisor. Engaging in activities being essential for life, one has to do activities. Otherwise, there was no necessity for service. "The right given to the husband to lead the family should not result in the misuse and abuse of his authority. Therefore, he should not ask his wife for things that are beyond her capacity or give her too many orders." (Al-Kaysi, p.92).

Regarding mutual rights and duties, the Qur'an clearly instructed:

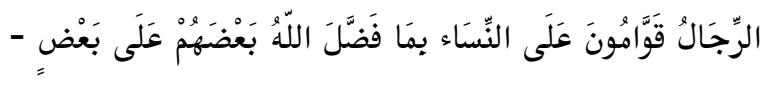

"Men are the protectors and maintainers of women, because Allah has made one of them to excel the other (Al-Qur'an:4:34).

Since service is for maintenance of life, it should not be so excessive that it robs the joy of life. Both husband and wife will have to feel each other with love and affection. 


\section{Ways of peaceful co- existence}

\section{(1)}

Marital contract is nothing but a quest for a companion in weal and woe in this sorrowful domestic life. If one has not got a companion according to him / her taste or choice, it is better not to share any painful experience with anyone. It is a matter of foolishness to repent for it and to disclose it to anyone. Rather, one should strive to adjust with him / her with smiling face. Proceed on any way. One should not lament for the past deeds. Success or failure comes by turns in the life of human being. In spite of all unfavorable situations a couple should try to lead a happy conjugal life. Pain and sorrow must not be harbored in the mind. People should not sigh, express dissatisfaction. Never complain to each other. This is the work of sinful person. In this situation spouse can go to traveling to minimize their internal tension. 'One of the provinces of India (Teregan) took initiative to mitigate the quarrels of family life, sending in a tourist spot for honey moon in a second time by the cost and expenditure of the authority of that Province. If any spouse seems to be broken, they would be sent to remote area for honey moon and advised by the psychologists.' (Prothom Alo, October 13, 2009). 'Malaysia also took same initiative like India. They are also sending the quarreled spouses to travel in the silent and distant areas or deep jungle with guide and psychologist. They believe that if the spouses travel together, the misunderstanding would be changed. The decision of divorce or separation might be withdrawn. For this reason, India and Malaysia started 'divorce tourism industry' to block separation of life.' (Prothom Alo, October $12,2009)$.On the other hand, the life of human being is very much limited. It is difficult task to constitute a domestic life breaking an already constituted domestic life, which has been established once. So, the domestic life should be advanced throwing all kinds of sorrow and pain. Sorrow or pain is sin, death and darkness. The new couple should fight against these.

Islam views it as a strong bond (mithaqun ghaleez), a challenging commitment in the fullest sense of the word. It is a commitment to life itself, to society and to the dignified, meaning survival of the human race. It is a commitment that married partners make to one another as well as to Allah. It is the kind of commitment in which they find mutual fulfillment and self-realization, love and peace, compassion and 
serenity, comfort and hope. All this is because marriage in Islam is regarded first and foremost as a righteous act, an act of responsible devotion. It was Allah who created mankind out of one living soul, and created of that soul a spouse so that he might find comfort and rest in her $(7: 107)$. And it is a sign of Allah that He has created for men, of themselves, mates to seek in their company peace and tranquility and has set between them mutual love and mercy. Surely in that are signs for those who complete $(30: 21)$. Even at the most trying times of married life, and in the midst of legal disputes and litigation, the Qur'an reminds the parties of Allah's law; it commands them to be kind to one another, truly charitable toward one another and above all dutiful to Allah. (Abd al-ati, 1996, pp.114-115)

\section{(2)}

Those who express malice to the love and affair of newly coupled life are accursed. They are narrow and mean minded. The hearts of those people are very much ugly. The couple should proceed towards avoiding such relatives and guardians. If needed for the time being, they can live separately leaving parents and family. If true love exists between the spouses, the greatest prosperity and happiness prevails in the family. If the family life is blessed with prosperity and happiness, society and state as well get benefits by it. Lack of love and affection in family life is the cause of thousands of restlessness, sorrow and death in families and societies. We should try to create a friendly environment among all the family members, like brother, sister, brother-in-law, sister-in-law, mother-in-law and so on. Those who hinder in the love and affair of conjugal life, actually inflict torture on the couple.

\section{(3)}

Sometimes it is seen that husband does not love his wife; rather he ignores and hates her. In such cases, wife will have to love him by all means from the core of her heart. She will have to wait with patience. No man can deny or ignore the actual love and affection.

The ideal wife combines three merits: she pleases her husband when he sees her, by taking care to appear beautiful before him; she obeys him when he gives a 
command, she does not go against his wishes regarding her person and property by doing anything of which he disapproves. (Al-Kaysi, p.94).

But love should not be concealed in the heart. It should be exposed to her husband through words and deeds. Women should never think herself narrow minded. She should maintain self-confidence in her. If husband drives her away she should never leave husband. "A husband should never revile his wife or her relatives." (Al-Kaysi, p.92). Husband should never spoil the prestige or image of his wife, as woman are dependant and sheltered. "The marriage contract should be taken as a serious, permanent bond. But if it does not work well for any valid reason; it may be terminated in kindness and honor, with equity and peace." (Abd al-ati, 1996, p.116)

(4)

If husband loves, cares, respects the wife, she as well should repay it by making a room for her in the heart of the husband. "Wives must do their best to keep their husbands pleased with them." (Al-Kaysi, p.94). To feel each other, to understand one another's sufferings are the happiness of conjugal life. In word, conduct and dealings; no one should show power or hegemony on the other. Husband will give gift, in the same way, wife also will give gift.

The role of the husband evolves around the moral principle that it is solemn duty to Allah to treat his wife with kindness, honor and patience; to keep her honorably or free her from the marital bond honorably; and to cause her no harm or grief (Qur'an2:229-230;4:19). The role of the wife is summarized in the verse that women have rights even as they have duties according to what is equitable.

(Abd al-ati, 1996, p.117)

(5)

Much prosperity and benefit bless the family through the attention and alertness of the wife. Due to this, solvency comes in spite of low income of the husband. If wife becomes inattentive and indifferent to the joy, sorrow and want of family, sufferings may increase in that family day by day. Before enjoying a luxurious life, she will have to understand the condition of her husband. "A wife should avoid asking a husband for extra money or for that which he does not possess and 
cannot provide, and she would show gratitude for whatever is given." (Al-Kaysi, p.94).

She would not lead her life as like as a guest at the house of husband. She will have to believe that this is her own house. In problems and difficulties in any case, she will have to participate and should be an economical woman, so that, they may get respects and love from all and happiness may come in that family.

What is true of the residence is true of clothing, food and general care. The wife has the right to be clothed, fed and cared for by the husband, in accordance with his means and her style of life. These rights are to be exercised without extravagance or miserliness. (Abd al-ati, 1996, p.118)

(6)

Eye and love cheat with men and women in many times. Love and affection felt before marital contract could be changed after marriage. That devotion and inclination might not remain in the mind of the couple. They can search for or dream of another male or female. For this, the advice of religion is to control the eyes and govern the mind. Otherwise, there is no value of love and affection. If one has love for his wife, if he has promise to her, never to leave him or her; never to be separated from him or her. One must have to love in secret and publicly. One must have full confidence on her or him. Otherwise, conjugal life can turn into adultery. "A wife should not be afraid to express her love and affection for her husband. It will please him and bind him closer to the family; moreover, if he does not find an attractive, loving woman at home, he may be driven for solace elsewhere outside the home." (Al-Kaysi, p.96). No one will meet Allah, no one will get Allah's grace avoiding wife, laughing at women, showing disrespect and negligence to women. The characteristic of Allah is fully reflected in the life of women. If mind is tired to wife, if the eye goes to sinful way, these should be brought back forcefully by the grace of Allah. Otherwise, the sorrow of life would be increased unaccountably. Husband and wife both are friends. Here, there is no inferior and superior. If husband sits at a lower seat and wife sits at a higher seat and gossip with each other, there is no problem in such situation. If wife has to take the dust of the leg of husband (salute), in the same way husband would also take the dust of the leg of wife. Or none will do any of these. A wife should never be considered as 
domestic slave. Sometimes husband should give money to the wife. But he would not ask her about this money how she spends it. A husband should never tell anyone about the guilty and weak point of wife. In the same way, a wife also should not blame, charge her husband. "Too many arguments and disputes with a husband, heaping abuse on him, leads, in fact, to hatred and a deterioration of the relationship."(Al-Kaysi, p.96). A husband should never request wife to do any kind of hard labor or risky job. For the psychological development of wife, husband can arrange few recreational activities like providing books, watching $\mathrm{TV}$, news paper. He can travel to various places with his wife. Naturally, women are being affected with many diseases most of the time. A husband should not show indifference or idleness in such cases without treatment. Womenfolk are usually very much respected in a Muslim society especially in this subcontinent. In this connection, it may be suggested that they should not be disrespected under any circumstances. If women are insulted, domestic life would not be prosperous. Allah says that:

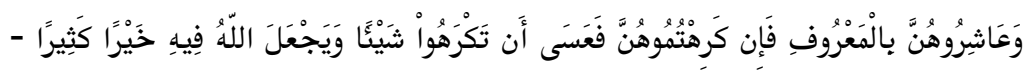

"And live with them honorably. If you dislike them, it may be that you dislike a thing and Allah brings through it a great deal of good."

(Al-Qur'an:4:19).

The Prophet (sm) also said: خير متاع الدنيا المرأة الصالحة.

"The best object of benefit of the world is the pious woman." (Muslim, Hadith No.3716, p.178).

Many are the statements of the Qur'an and the Sunnah that prescribe equity, compassion and love, sympathy and consideration, patience and good will. The Prophet (sm) goes as far as to declare that the best Muslim is the one who is best to his family, and the greatest, most blessed joy in life is a good, righteous wife. (Abd al-ati, 1996, p.117)

As a guardian of the family husband should show the equal treatment in their conjugal life.

It is the husband's duty to consort with his wife in an equitable and kind manner. One specific consequence 
of this Divine command is his responsibility for the full maintenance of the wife, a duty which he must discharge cheerfully, without reproach, injury, or condescendence. (Abd al-ati, 1996, p.117)

\section{(7)}

Husband and wife should understand and value the psychology of each other. Both spouses should not be angry at the same time. If one of the spouses becomes upset, it is best if the other tries to remain calm and collected. If husband does not like a person who is fond of the wife, she should avoid him. "It is a wife's duty not to allow anyone that her husband does not want to enter the house without his permission."(AlKaysi,p.94). Directly both husband and wife will never expose opposite mentality with each other. If taste and mentality were different before marital contract, it should be same after marital contract. Dearth and want would remain in the domestic life disregarding their unfavorable situations, both should work together. The parents, brothers and relatives should be treated like the own parents or siblings. It is not right way to insult or ignore or think helpless the relatives of husband. Because of this, the complexity of family life increases day by day. "For the wife to hold her husband's close relatives in respect and treat them kindly is, in fact, a mark of respect and honor for the husband."(Al-Kaysi, p.95). Husband and wife both may do wrong. One should not hassle with the faults of the other for long. In married life, both will express deep love and affection, so that conjugal life will be happy and peaceful.

To fulfill the basic obligation, the wife must be faithful, trustworthy and honest. More specifically, she must not deceive her mate by deliberately avoiding conception lest it deprive him of legitimate progeny. Nor must she allow any other person to have access to that which is exclusively the husband's right, i.e. sexual intimacy. A corollary of this is that she must not receive or entertain strange males in her home without his knowledge and consent. Nor may she accept their gifts without his approval. This is probably meant to avoid jealousy, suspicion, gossip, etc., and also maintain the integrity of all parties concerned. The husband's possessions are her trust. If she has access to any portion thereof, or if she is entrusted with any fund, she must discharge her duty 
wisely and thriftily. She may not lend or dispose of any of his belongings without his permission. (Abd alati, 1996, pp.118-119).

Regarding the fact, sayngs of Prophet (sm) are:

$$
\text { أيما إمرأة ماتت وزوجها عنها راض، دخلت الجنة. }
$$

"Whatever wife died and her husband was satisfied with her, she entered paradise." (Hakim,1990, Hadith No.191, p.191).

$$
\text { المرأة راعية على بيت زوجها ، وهي مسئولة. }
$$

"A wife is a guardian of her husband's house and she is responsible (for it)” (Bukhari, Hadith No.4904, p.1996).

\section{Conclusion:}

In conclusion, I want to say that ethics and morality as well as Islamic norms and conducts may help to make a sweetest conjugal life. It can be very hurting for another person to be reminded of past mistakes. In Islam, it is generally not recommended to dwell on the past.

Following points are very much important:

1. Duties of husband towards wife:

a. He shall not be too strict to her in order to make her conform to his views.

b. He shall not hate her.

c. He shall give enough time to keep company with his wife in amusing pursuits.

d. He shall allow none to interfere in their conjugal matters and tries into the secrets of their sexual life.

e. He shall give her education

2. Duties of wife towards husband:

a. She shall be obedient in all respect.

b. She shall guard her chastity

c. She shall look after his possessions in his absence and shall protect herself against sins. 
Allah knows that the human heart is not a static entity, it is sometimes weak and at times dynamic. Feelings can and do change with time. Love may wither and fade away. The marital bond might weaken if not properly cared for. Happiness in marriage cannot be taken for granted; continuous happiness requires constant giving from both sides. For the tree of marital love to remain alive and keep growing, the soil has to be sustained, maintained, watered and nurtured. (http://www.ilmfruits.com/ten-tips-for-a-happy-andsuccessful-marriage)

A husband always tries his best to be good to his wife by words and by deeds. Talk to her, smile to her, seek her advice, ask for her opinion, spend quality time with her and always remember that the Prophet (sm.) said, 'The best of you are those who are best to their wives.' Preidea is very much essential regarding conjugal life. Like Christian Church; seminar, symposium can be arranged regarding married life in college and university level where prospective bride and groom will attend as the participants. So that, male and female may get a clear concept about their conjugal life. Regarding the conjugal life, articles, stories and essays can be written in curriculum books where family manners accountability and responsibility to father and mother-in-law, neighbors, fostering new born child should be mentioned in details. From such kind of training spouse, parents and family may get enough benefit which can bring peace and tranquility in our society and it can calm down the tendency and trend of breaking marriages. 


\section{References:}

ABD AL-ATI, HAMMUDAH (1977), "The Family Structure in Islam", American Trust Publications. USA.

ABD AL-ATI, HAMMUDAH, (1996) "Islam in Focus", Second edition, Islamic teaching centre, U.S.A \& Canada.

AL-KAYSI, MARWAN IBRAHIM (1986), "Morals and Manners in Islam, A Guide to Islamic Adab" The Islamic Foundation, London.

AL-NASA'I, IMAM (1986), "Sunan al-Sughra hadith", Vol.6, Maktab alMatboaat al-Islamiyyah Halab, Third edition, Syria.

AL-TIRMIDHI, IMAM (N.D), "Sunan al-Tirmidhi hadith", Vol.5, Darun Ihyaut Turath al-Arab, Beirut.

BUKHARI, IMAM (1987) "Sahih Bukhari hadith" Vol.5, Darun Ibn Kathir Al-Yamama, Third edition, Saudi Arabia.

HAKIM (1990), “Alhakim Fil Mostadrak”, Vol.4, Darul Kotob al Ilmiyyah, First edition, Beirut.

IBN AL-HAJJAJ, IMAM MUSLIM (N.D) "Sahih Muslim hadith", Vol.2, Darun Ihyaut Turath Al-arab, Beirut.

IBN AL-HAJJAJ, IMAM MUSLIM (N.D) "Sahih Muslim hadith”, Vol.4, Darul Jeel, Beirut.

KHANUM, RASHIDA AKTHER (2008) "Feminism, Status of Women and Islam", Empowerment, A journal of women for women, Dhaka, Vol.15.

NOORDEEN, A.S. (1992), “Women in Shariah”, $3^{\text {rd }}$ ed. Malaysia.

SABIRUDDIN, (1996)"A Muslim husband and wife: Rights and duties", Islamic Book Service, Idara Islamiyat-e-Diniyat,/ Kitab Bhabvan, New Delhi, India.

SHAMSUL ALAM, A.Z.M, (1995), "Family values" $1^{\text {st }}$ ed. Bangladesh Cooperative Book Society, Dhaka.

Al-Qur'an

Prothom Alo, The daily news paper in Bangla, Dhaka, Bangladesh, 13 October, 2009.

http://www.ilmfruits.com/ten-tips-for-a-happy-and-successful-marriage. 